УДК 930.25:[355.23:355.425:329.15](477.63)“1917/1921”

DOI: 10.33099/2707-1383-2021-39-1-128-139

\title{
Сергій Зайцев
}

аспірант кафедри історичного краєзнавства,

Львівський національний університет

імені Івана Франка (Львів, Украӥна)

ORCID: https://orcid.org/0000-0003-2277-9345

Електронна nошта: sergiystepovik@ukr.net

\section{БОЙОВИЙ ВИШКІЛ БІЙЦІВ \\ ПОВСТАНСЬКО-ПАРТИЗАНСЬКИХ ФОРМУВАНЬ КАТЕРИНОСЛАВЩИНИ ПЕРІОДУ УКРАЇНСЬКОЇ РЕВОЛЮЦІЇ (1917-1921)}

\begin{abstract}
У статті на основі архівних та опублікованих матеріалів здійснено спробу дослідити особливості бойового вишколу, котрий, як процес військового навчання, був характерним явищем у середовищі учасників більшовицьких, проукраӥнських і анархістських повстансько-партизанських формувань, щзо діяли на території Катеринославщини в період Української револючії 1917-1921 рр. Значну увагу приділено його головним принциипам. Наведено приклади напрямків бойових тренувань і навичок, які здобувалися бійиями внаслідок них.

Ключові слова: бойовий вишкіл, Украӥнська револючія, повстансько-партизанський рух, Катеринославщиина, більшовизм, проукраӥнські сили, анархізм.
\end{abstract}

Постановка проблеми. Досвід ведення збройної боротьби, як у давнину, так і в сьогоденні, показує, що однією з умов успішного проведення бойових операцій виступає правильно налагоджений процес навчання особового складу підрозділів військовій справі, складовою частиною якого є бойовий вишкіл. Тому, безумовно, значну увагу бойовій підготовці приділяли збройні формування, що діяли на українських землях, у тому числі й на теренах Катеринославщини, у період революційних потрясінь 1917-1921 рр. Особливу нішу серед цих формувань посідали нерегулярні повстанські та партизанські бойові одиниці, підготовка яких часто відзначалася специфічним характером.

Аналіз наукових досліджень і публікацій, присвячених революційним подіям 1917-1921 рр. на Катеринославщині, вказує, що питан- 
ня, пов'язані 3 бойовим вишколом тамтешніх іррегулярних мілітарних підрозділів, на сьогоднішній день переважно лишаються поза увагою дослідників і потребують грунтовного вивчення. Серед праць, які почасти торкаються вказаної тематики, можна виділити роботи дослідників історії більшовицької Червоної гвардії В. Борщевського (Борщевський, В. 1948, с. 41-60) та А. Конєва (Конев, А. М. 1989), українських бойових формувань Вільного козацтва В. Бондаренка (Бондаренко, В. Г. 2010) та анархістських загонів Нестора Махна — О. Тимощука (Тимощук, А. В. 1996).

Мета дослідження полягає у висвітлені особливостей та характерних рис бойового вишколу більшовицьких, проукраїнських та анархістських іррегулярних бойових формувань Катеринославщини у 1917-1921 pр.

Виклад основного матеріалу. Бойовий вишкіл особового складу військового підрозділу є однією із запорук успішного ведення бойових дій. Він являє собою цілеспрямований i організований процес військового навчання i виховання особового складу військовій справі та бойового злагодження військових підрозділів для виконання бойових завдань і забезпечення бойових дій відповідно до їх призначення. Основною метою бойового вишколу $\epsilon$ забезпечення постійної боєготовності військ і органів управління, підвищення їхньої боєздатності та ефективності взаємо- дії (Родионов, И. Н. глав. ред. 1997, с. 498).

Бойовий вишкіл $є$ невід'ємною та обов'язковою складовою життя будь-якого регулярного армійського формування. Важливу роль він відігравав і продовжує відігравати й у середовищі іррегулярних бойових утворень. Недарма, один із головних лідерів Кубинської революції 1953-1959 рр. Ернесто Гевара, який до того ж був досвідченим партизаном-підпільником, зазначав: «бойова підготовка солдата-визволителя це саме життя партизанського загону” (Гевара, Э. 1961). Вона перебувала у центрі уваги й очільників усіх політичних сил, які у 1917-1921 рр. мали свої іррегулярні мілітарні загони на території Катеринославщини. Із відомих на сьогодні джерел можна спробувати дослідити та проаналізувати їі особливості та характерні риси у вказаному регіоні.

Ключовими представниками нерегулярних бойових формувань краю виступали прихильники більшовизму, анархізму, а також проукраїнських урядів Української Центральної Ради та Директорії Української Народної Республіки. Протягом цих чотирьох років керівництво більшості загонів, кожної із вказаних політико-ідеологічних течій, створюючи власні бойові підрозділи, чималу увагу приділяло їхньому бойовому вишколу, сподіваючись таким чином підвищити свої шанси на перемогу в боротьбі за владу в регіоні. 
Більшовики Катеринославщини першими серед інших претендентів на владу усвідомили неминучість збройних зіткнень у боротьбі за право панування в регіоні, а тому, вже з перших днів революції приступили до формування своїх бойових загонів у вигляді Червоної гвардії. Головним осередком організації червоногвардійських підрозділів став Катеринослав зі своїми робітничими околицями, де лише протягом весни 1917 p. було утворено близько десятка пробільшовицьких формувань. Закономірно, що при їх впорядкуванні, чимала увага повинна була надаватись бойовому вишколу особового складу новостворених мілітарних одиниць. Однак, через нестачу досвідчених інструкторів, які би мали належну військову освіту та підготовку, керівництву деяких загонів доводилося обмежувати прийом бажаючих вступити до їхніх лав. Ситуація змінилася на початку червня 1917 р., коли на загальних зборах членів Червоної гвардії Катеринослава іiі представниками було розглянуто пропозиції з налагодження та поліпшення бойової підготовки загонів та необхідності вивчення тактики ведення бойових дій (Потапов, М. 1957, с. 255-256). Вочевидь, саме ця подія стимулювала місцеве більшовицьке керівництво до запровадження у розпорядок дня бійців червоногвардійських загонів регулярних тренувань спрямованих на здобуття навичок користування зброєю та засвоєння принципів ведення бойових дій, оскільки саме з цього часу починають зустрічатися згадки про проведення занять із бойової підготовки для червоногвардійців (Амосов. 1927, с. 117; Войцехович, А. и др. 1927, с. 166; Левченко, М. 1957, c. 315; Суханов, А. 1922, с. 109).

Аналогічні зрушення відбувалися на початку літа 1917 р. і в інших червоногвардійських формуваннях. Так, у сусідньому з Катеринославом місті Кам'янському організація занять із навчання бійців військової справи належала цеховим профорганізаціям Дніпровського заводу (Васильєв, I. 1957 , c. 394).

Спробуємо розглянути головні принципи, покладені в основу бойового вишколу загонів Червоної гвардії Катеринославщини у період їхнього формування в 1917 - на початку 1918 pp.

Зрозуміло, що для проведення занять із вивчення військової справи, були потрібні спеціально відведені та облаштовані для цього місця. Для вирішення цієї проблеми кожен червоногвардійський загін мав індивідуальний підхід. Так, члени найпотужнішої в Катеринославі Червоної гвардії, організованої при Брянському загоні, проводили свої тренування у місцевому саду Сокольники (Гонтарь. 1927, с. 177). Сучасниця революційних подій на Катеринославщині Феодора Лукашенко-Шведова у своїх спогадах зазначала, що молоде поповнення Червоної гвардії від земської лікарні Катериносла- 
ва опановувало військову справу на спеціально відведеній ділянці цієї ж лікарні ${ }^{1}$. Червоногвардійці робітничих околиць Катеринослава нерідко займалися на вулицях своїх поселень (Суханов, А. 1922, с. 109). У місті Кам'янському, в залежності від напрямку підготовки особового складу, тренування відбувалися на галявині навпроти штабу тамтешньої Червоної гвардії, на вулицях міста чи у плавнях (Васильєв, І. 1957, с. 399).

Там, де не було можливості використовувати властивості прилеглої території для облаштування тренувальних ділянок, заняття 3 бойової підготовки проводилися безпосередньо на робочих місцях. Так, один iз очевидців тих подій: житель Катеринослава Зиновій Арбатов зазначав, що заняття тамтешніх червоногвардійців відбувалися на самих заводах (Арбатов, 3. Ю. 1923, с. 85). Це підтверджується словами бійця одного iз загонів Червоної гвардії Катеринослава, котрий згадував, що навчання бойовій справі у його підрозділі проходило у заводській їдальні².

Безумовно, що для проведення занять із бойової підготовки висту-

1 Державний архів Дніпропетровської області (далі - ДАДО). Ф. Р-4439. Оп. 1, Спр. 4. Воспоминания Лукашенко-Шведовой Феодоры Дорофеевны о своей революционной деятельности и своего мужа Лукашенко Тимофея Митрофановича. Арк. 7.

2 ДАДО. Ф. Р-3493. Оп. 1. Спр. 25. Стенограмма выступлений старых коммунистов участников борьбы за власть Советов 19171918 гг. в г. Екатеринославе. Арк. 35. пала нагальна потреба у компетентних i досвідчених інструкторах. Ними зазвичай ставали демобілізовані учасники Першої світової війни, котрі мали бойовий досвід ${ }^{3}$ (Baсильєв, I. 1957, с. 399; Суханов, А. 1922, с. 109). Зустрічалися й випадки відрядження спеціальних інструкторів для навчання робітників військовій справі. Наприклад, відомо про приїзд таких інструкторів-матросів та червоногвардійців із Петрограду для тренувань бійців Червоної гвардіï Катеринослава ${ }^{4}$ (Амосов. 1927, с. 117; Войцехович, А. и др. 1927, c. 166; Пахоменков, Ю. Г., \& Юзбашева, Н. Л. уклад. 2016, с. 119).

Чому ж саме навчалися члени більшовицьких іррегулярних бойових формувань? Однією 3 найголовніших навичок, яку опановували новобранці, було відпрацювання прийомів із вогнепальною зброєю (Арбатов, 3. Ю. 1923, с. 85). Як згадував один із організаторів Червоної гвардії в Катеринославі Михайло Потапов (1957):

«Кожен 3 нас, червоногвардійців, не розлучався 3 гвинтівкою, міцно подружив 3 нею. Працював червоногвардієць біля верстата — i поруч

3 ДАДО. Ф. Р-4439. Оп. 1, Спр. 4. Воспоминания Лукашенко-Шведовой Феодоры Дорофеевны о своей революционной деятельности и своего мужа Лукашенко Тимофея Митрофановича. Арк. 7.

4 ДАДО. Ф. Р-3493. Оп. 1. Спр. 25. Стенограмма выступлений старых коммунистов участников борьбы за власть Советов 19171918 гг. в г. Екатеринославе. Арк. 35. 
3 ним була гвинтівка. Під час обідньої перерви, нашвидку перекусивши, він ішов вправлятися з гвинтівкою» (с. 257).

При нестачі бойової вогнепальної зброї іiі могли заміняти дерев'яними макетами 5 .

Не менш важливим елементом бойового вишколу червоногвардійських загонів Катеринославщини було відпрацювання ведення прицільного вогню з ручної стрілецької зброї (Войцехович, А. и др. 1927, c. 166; Потапов, М. 1957, с. 257). Стрільбища облаштовувалися в спеціально відведених і віддалених від людського ока місцях, якщо це дозволяли властивості місцевості. Наприклад, бійці кам'янської Червоної гвардії вправлялися у стрільбі в плавнях (Васильєв, І. 1957, с. 399).

Ще одним важливим елементом бойового вишколу, якому навчали червоногвардійських новобранців, була муштра (Арбатов, 3. Ю. 1923, c. 85 ; Суханов, А. 1922, c. 109). Ïï peгулярне виконання дозволяло бійцям Червоної гвардії набути злагодженості при роботі у підрозділах, що, як відомо, дуже знадобилося їм уже в найближчому майбутньому.

Щоправда, така велика увага бойовій підготовці приділялася не у всіх червоногвардійських загонах Кате-

5 ДАДО. Ф. Р-4439. Оп. 1, Спр. 4. Воспоминания Лукашенко-Шведовой Феодоры Дорофеевны о своей революционной деятельности и своего мужа Лукашенко Тимофея Митрофановича. Арк. 7. ринославщини. Наприклад, відомо, що керівництво Червоної гвардії Павлограда не проводило бойових навчань зі своїм особовим складом. Причиною цього була нестача зброї (Швед, А. 1927, с. 160). Однак, слід вважати, що такі випадки були нечастими.

Заняття з бойової підготовки проводилися і в організованих більшовиками Катеринославщини партизанських загонах. Так, відомо, що такі заходи здійснювалися в очолюваному Кузьмою Лантухом загоні «За владу рад», який діяв проти білогвардійських військ генерала Антона Денікіна восени 1919 р. ${ }^{6}$

Практикувалось у більшовицьких іррегулярних підрозділах і відрядження перспективних бійців на спеціальні військові курси. Про один iз таких випадків згадував більшовицький партизанський командир Микита Макаров-Нікітін, вказуючи, що у вересні 1918 р. із його партизанського загону до Москви відряджено групу молоді в кількості п’яти осіб на військові курси червоних командирів ${ }^{7}$.

Не нехтували бойовим вишколом також і місцеві проукраїнські

${ }^{6}$ ДАДО. Ф. Р-3493. Оп. 1. Спр. 41. Воспоминания бывшего командира партизанского отряда «За власть советов», действовавшего на Екатеринославщине в 1919 г. — К. Р. Лантуха. Арк. 4.

7 ДАДО. Ф. Р-4533. Оп. 1. Спр. 1. Воспоминания Макарова-Никитина Н.М. об его участии в гражданской войне 1918-1919 г. Арк. 21. 
мілітарні формування. Про це свідчить низка документів та згадок їх безпосередніх учасників. Так, одне iз положень, розробленого та прийнятого в Катеринославі у жовтні 1917 р. «Статуту робітничої організації «Вільне козацтво», передбачало обов'язкове проведення муштри для усіх їі членів згідно із планом затвердженим радою куреня. Муштра повинна була відбуватися під особистим керівництвом сотенних старшин та доглядом осавулів ${ }^{8}$.

У «Статуті «Вільного козацтва» України», затвердженого 13 листопада 1917 р., при переліку положень, які становили мету організації, згадувалося про необхідність фізичного розвитку іiі членів. Далі вказувалося, що для здійснення своїх завдань вільнокозацькі товариства, поряд iз іншими заходами, повинні організовувати гімнастичні курси та спортивні регулярні вправи (Верстюк, В. Ф. упорядн. \& Смолій, В. А. ред. 1996, с. 435).

Також відомо, що після відбиття у грудні 1918 р. Катеринослава від махновців, бійці Запорозької Січі Юхима Божка багато часу присвячували муштрі та вивченню усіх видів зброї (Гонта, Д. 1957, с. 111). Це, фактично, перетворювало їх на тогочасних універсальних солдатів.

8 ДАДО. Ф. 566. Оп. 1 дод. Спр. 4. Устав организации «Вільне козацтво», распоряжения Центральной Рады и Министерства путей сообщения Украины. Арк. 2-2 зв.
Проте не усі українські повстанські та партизанські формування могли похизуватися високим рівнем бойового вишколу свого особового складу. Так, один із членів Лисогірського повстансько-партизанського куреня Гаврило Гордієнко стверджував, що деякі із представників вказаного підрозділу, вже ведучи влітку 1919 р. бойові дії проти більшовиків, не вміли користуватися вогнепальною зброєю (Гордієнко, Г. 1976, c. 183-184). Вочевидь, такі випадки були непоодинокими, оскільки організовувати якісне бойове навчання особового складу міг собі дозволити не кожний повстанський або партизанський ватажок, а кількість осіб, котра проходила службу в армії, серед рядового складу мілітарних загонів не завжди була високою, через їх молодий вік. Окрім того, зважаючи на стихійність повстанських виступів у регіоні, не завжди існувала можливість налагодити якісний процес військових навчань нашвидкуруч сформованих загонів. Так, Юрко Степовий (Федір Пестушко) згадував, що бойовий вишкіл бійців Степової дивізії, сформованої у 1920 р. його братом Костем Степовим-Блакитним (Костянтином Пестушком), відбувався наспіх (Степовий, Ю. 1947, с. 43).

Чи не найкраще розвиненою бойова підготовка серед повстансько-партизанських загонів Катеринославщини була у Революційно-повстанській армії України (махновців) (далі РПАУ), що діяла в регіоні у другій 
половині 1919 - початку 1920 рр. Її високий рівень відзначали навіть білогвардійці, котрим повстанська та партизанська бойова діяльність махновських підрозділів завдала чи не найбільшої шкоди. Ось що згадував про бойову підготовку сил Н. Махна його супротивник білогвардійський генерал Яків Слащов (1991):

«Кидається у вічі вміння Махна швидко формувати та збивати свої частини (за міркою громадянської війни взагалі міліційного характеру) в хороші регулярні війська, які вперто б’ються» (Слащев, Я. 1991, с. 85).

При цьому в махновській армії мав місце вишкіл як рядового, так i командного складу. Бойовий вишкіл рядового складу поділявся на перепідготовку вже навчених бійців, котрі пройшли службу в колишній імператорській армії та на вишкіл бійців, що не мали жодного бойового досвіду. Першу категорію повстанців перепідготовляли з методів ведення світової війни на громадянську. Для вишколу новачків проводилися інтенсивні заняття. В основі програми бойової підготовки лежала абсолютна спеціалізація повстанця. Інструкторами для новобранців виступали більш досвідчені товариші по службі. Навчання поділялося на групове, де бійці опановували навички за родом військ - піхоти або кавалерії, та індивідуальне, де давалися знання з певної спеціалізації - кулеметника, артилериста. На прискореність курсів підготовки вказує витрачена для виконання цього завдання кількість годин. Так, на вишкіл піхотинця йшло 50 годин, 3 яких по 20 годин відводилися на муштру і вогневу підготовки та 10 годин - на інженерну підготовку. Підготовка кавалериста займала 70 годин, із котрих 30 годин йшло на стройові кінні та піші заняття, 20 годин - на вогневу підготовку та по 10 годин на інженерну підготовку та заняття 3 догляду за конем. Артилериста готували 60 годин, відводячи при цьому по 20 годин стройовій, вогневій та інженерній підготовці (Белаш, А. В. \& Белаш, В. Ф. 1993, с. 387-388).

На цьому заняття з бойового вишколу не припинялися, а продовжували займати важливе місце у житті бійців РПАУ. Наприклад, відомо, що командувач махновськими військами Кримського напрямку Всеволод Павловський рекомендував підлеглим йому командирам частин проводити зі своїм особовим складом щоденні тригодинні тактичні польові навчання (Данилов, В. \& Шанин, Т. ред. 2006, с. 273).

Окремо у махновській армії відбувався бойовий вишкіл командного складу всіх рівнів. Для них, як правило, не проводилося жодних спеціальних курсів, проте була організована практика (практичне навчання) у якості помічників старших товаришів на тій посаді, куди вони були обрані. Однак, є відомості й про наявність командних курсів, що мали на меті здійснювати теоретичне навчан- 
ня обраних повстанцями командирів (Белаш, А. В. \& Белаш, В. Ф. 1993, c. 383,388$)$.

Чудовий приклад особовому складу подавав і сам їх ватажок Н. Махно. Відомо, що влітку 1918 р., організовуючи із селян партизанські групи для боротьби з австрійцями, він навчав їх володінню вогнепальною зброєю (Махно, Н. 1937, с. 36). А за згадкою одного з учасників анархістського руху Степана Дибеця:

«Прекрасно володів усіма видами зброї. Добре знав гвинтівку, чудово володів шаблею. Влучно стріляв із маузера та нагана. 3 гармати міг стріляти. Це імпонувало усьому його найближчому оточенню - сам батько Махно стріляє із гармати»
(Белаш, А. В. \& Белаш, В. Ф. 1993, c. 123).

Висновки. Підсумовуючи вищевикладений матеріал, можна переконатися, що головними учасниками повстансько-партизанського руху на теренах Катеринославщині у 19171921 рр. були більшовицькі, українські й анархістські нерегулярні бойові формування. Бойовий вишкіл відігравав вагому роль у їх військовій діяльності. Його рівень був неоднаковим у різних підрозділах і залежав від низки факторів. Подальше вивчення розглянутої проблеми дозволить глибше зрозуміти принципи бойової підготовки повстансько-партизанських військ у регіоні часів Української революції 1917-1921 рр.

\section{СПИСОК ВИКОРИСТАНИХ ДЖЕРЕЛ І ЛІТЕРАТУРИ}

Амосов. (1927). Октябрьские дни на Екатеринославщине. В: Борьба за Советьл на Екатеринославщине: сборник воспоминаний и статей. Днепропетровск: Издание Днепропетровского Истпарта и Окружной комиссии по проведению 10-летия Октябрьской революции, с. 104-120.

Арбатов, 3. Ю. (1923). Екатеринослав, 1917-1922 гг. Архив русской революичи. 12 , c. $85-120$.

Белаш, А. В. \& Белаш, В. Ф. (1993). Дороги Нестора Махно: историческое повествование. Київ, с. 591.

Бондаренко, В. Г. (2010). Історія новітніх запорожців: вільнокозацький рух на Півдні України (1917-1918 рр.). Запоріжжя: ТОВ «ЛІПС» ЛТД, с. 228.

Борщевський, В. (1948). Червона гвардія Катеринослава в боротьбі за владу Рад. Вогні Придніпров'я: літературно-художній та громадсько-політичний альманах. 1, с. 141-160.

Васильєв, І. (1957). Робітники Дніпровського заводу в боях за перемогу Жовтня. В: Бориі за Жовтень розповідають. (Спогади учасників боротьби за владу Рад на Катеринославщині). Дніпропетровськ, с. 382-402.

Верстюк, В. Ф. упоряд. \& Смолій, В. А. відп. ред. (1996). Украӥнська Центральна Рада: документи і матеріали у 2 т.: т. 1.: 4 березня - 9 грудня 1917 р. Київ: Наукова думка, с. 587. 
Войцехович, А. и др. (1927). Завод Рудзского в борьбе за Советы. В: Борьба за Советь на Екатеринославщчие: сборник воспоминаний и статей. Днепропетровск: Издание Днепропетровского Истпарта и Окружной комиссии по проведению 10-летия Октябрьской революции, с. 162-168.

Гевара, Э. (1961). Партизанская война. URL: http://militera.lib.ru/science/guevara/03.html [дата зверн.: 15. 01. 2021].

Гонта, Д. (1957). Отаманщина: (отаман Божко). Київ. 2-3 (41-42), с. 106-115.

Гонтарь. (1927). Воспоминания о Красной гвардии. В: Борьба за Советь на Екатеринославщине: сборник воспоминаний и статей. Днепропетровск: Издание Днепропетровского Истпарта и Окружной комиссии по проведению 10-летия Октябрьской революции, с. 176-184.

Гордієнко, Г. (1976). Під щзитом Марса. Філадельфія, 369 с.

Данилов, В. \& Шанин, Т. ред. (2006). Нестор Махно. Крестьянское движение на Украине. 1918-1921: документы и материалы. Москва: «Российская политическая энциклопедия», $1000 \mathrm{c}$.

Конев, А. М. (1989). Красная гвардия на защите Октября. Москва: Наука, 336 с.

Левченко, М. (1957). Більшовики Катеринінської залізниці в 1917-1918 pp. В: Бориі за Жовтень розповідають. (Спогади учасників боротьби за владу Рад на Катеринославщині). Дніпропетровськ, с. 292-335.

Махно, Н. (1937). Украинская революиия (июль-декабрь 1918 г.). Париж: Издание комитета Н. Махно, 184 с.

Пахоменков, Ю. Г. \& Юзбашева, Н. Л. уклад. (2016). Українська революиія 1917-1921 рр.

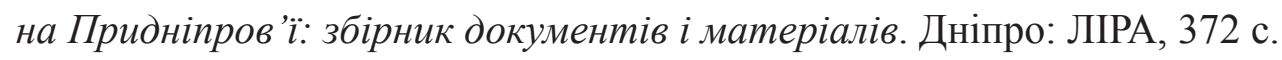

Потапов, М. (1957). Червона гвардія Катеринослава. В: Боротьба за перемогу Радянської влади на Україні: збірник спогадів учасників Великої Жовтневої сочіалістичної революиї. Київ: Держполітвидав. УРСР, с. 253-273.

Родионов, И. Н. глав. ред. (1997). Военная Энциклопедия: в 8 т.: т. 1: «А»-Бюлов. Москва: Воениздат, 639 с.

Слащев, Я. (1991). Екатеринославская операция. В: Нестор Иванович Махно: воспоминания, материаль и документыл. Київ: Дзвін, с. 84-92.

Степовий, Ю. (1947). В Херсонських степах. Мюнхен: Культура, 127 с.

Суханов, А. (1922). Завоевание власти. В: Пятая годовщина Октябрьской револющии, 1917-октябрь-1922. Екатеринослав: 1-я советская типография, с. 106-113.

Тимощук, А. В. (1996). Анархо-коммунистические формирования Н. Махно (сентябрь 1917 - август 1921 г.). Симферополь: Таврия, 190 с.

Швед, А. (1927). Павлоградская организация большевиков в 1917 г. В: Борьба за Советь на Екатеринославщчин: сборник воспоминаний и статей. Днепропетровск: Издание Днепропетровского Истпарта и Окружной комиссии по проведению 10-летия Октябрьской революции, с. 158-161. 


\section{REFERENCES}

Amosov. (1927). Oktyabr'skie dni na Ekaterynoslavshhine [October days in the Ekaterynoslav region]. In: Bor'ba za Sovety na Ekaterynoslavshhine: sbornik vospominaniy $i$ statey. Dnepropetrovsk: Izdanie Dnepropetrovskogo Istparta i Okruzhnoy komissii po provedeniyu 10-letiya Oktyabr'skoy revolyucii, s. 104-120. [in Russian].

Arbatov, Z. Yu. (1923). Yekaterinoslav, 1917-1922 gg. [Ekaterynoslav, 1917-1922]. Arkhiv russkoy revolyucii. 12, s. 85-120. [in Russian].

Belash, A. V. \& Belash, V. F. (1993). Dorogi Nestora Makhno: istoricheskoe povestvovanie [Roads of Nestor Makhno: historical narration]. Kyiv, 591 s. [in Russian].

Bondarenko, V. H. (2010). Istoriia novitnikh zaporozhtsiv: vilnokozatskyi rukh na Pivdni Ukrainy (1917-1918 rr.) [History of the newest Cossacks: the Free Cossack movement in the South of Ukraine (1917-1918)]. Zaporizhzhia: TOV «LIPS» LTD, 228 s. [in Ukrainian].

Borshchevskyi, V. (1948). Chervona hvardiia Katerynoslava v borotbi za vladu Rad [Katerynoslav's Red Guard in the struggle for Soviet power]. Vohni Prydniprov'ia: literaturnokhudozhnii ta hromadsko-politychnyi almanakh. 1, s. 141-160. [in Ukrainian].

Vasyl'iev, I. (1957). Robitnyky Dniprovs'koho zavodu v boiakh za peremohu Zhovtnia [Workers of the Dnieper plant in the battles for the victory of October]. In: Bortsi za Zhovten 'rozpovidaiut'. (Spohady uchasnykiv borot'by za vladu Rad na Katerynoslavschyni). Dnipropetrovs'k, s. 382-402. [in Ukrainian].

Verstiuk, V. F. uporiad. \& Smolii, V. A. vidp. red. (1996). Ukrainska Tsentralna Rada: dokumenty $i$ materialy u 2 t.: t. 1.: 4 bereznia - 9 hrudnia 1917 r. [Ukrainian Central Rada: documents and materials in 2 vols. Vol. 1.: March 4 - December 9, 1917]. Kyiv: Naukova dumka, 587 s. [in Ukrainian].

Voytsekhovich, A. i dr. (1927). Zavod Rudzskogo v borbe za Sovety [Rudzsky's plant in the fight for the Soviets]. In: Borba za Sovety na Ekaterynoslavshchine: sbornik vospominaniy i statey. Dnepropetrovsk: Izdanie Dnepropetrovskogo Istparta i Okruzhnoy komissii po provedeniyu 10-letiya Oktyabr'skoy revolyucii, s. 162-168. [in Russian].

Gevara, E. (1961). Partizanskaya voyna [Guerrilla war]. URL: http://militera.lib.ru/science/ guevara/03.html [Accessed: 15.01.2021]. [in Russian].

Honta, D. (1957). Otamanshchyna: (otaman Bozhko). Kyiv. 2-3 (41-42), s. 106-115. [in Ukrainian].

Gontar'. (1927). Vospominaniya o Krasnoy gvardii [Memories of the Red Guard]. In: Bor'ba za Sovety na Ekaterynoslavshhine: sbornik vospominaniy i statey. Dnepropetrovsk: Izdanie Dnepropetrovskogo Istparta i Okruzhnoy komissii po provedeniyu 10-letiya Oktyabr'skoy revolyucii, s. 176-184. [in Russian].

Hordiienko, H. (1976). Pid shchytom Marsa [Under the shield of Mars]. Filadelfiia, 369 s. [in Ukrainian]. 
Danilov, V. \& Shanin, T. red. (2006). Nestor Makhno. Krestyanskoe dvizhenie na Ukraine. 1918-1921: dokumenty i materialy [Nestor Makhno. Peasant movement in Ukraine. 1918-1921: Documents and materials]. Moskva: «Rossiyskaya politicheskaya entsiklopediya», $1000 \mathrm{~s}$. [in Russian].

Konev, A. M. (1989). Krasnaya gvardiya na zashchite Oktyabrya [Red Guard in defense of October]. Moskva: Nauka, 336 s. [in Russian].

Levchenko, M. (1957). Bil'shovyky Katerynins'koi zaliznytsi v 1917-1918 rr. [Bolsheviks of the Catherine Railway in 1917-1918]. In: Bortsi za Zhovten' rozpovidaiut'. (Spohady uchasnykiv borot'by za vladu Rad na Katerynoslavschyni). Dnipropetrovs'k, s. 292-335. [in Ukrainian].

Makhno, N. (1937). Ukrainskaya revolyutsiya (iyul-dekabr 1918 g.) [Ukrainian revolution (July-December 1918)]. Parizh: Izdanie komiteta N. Makhno, 184 s. [in Russian].

Pakhomenkov, Yu. H. \& Yuzbasheva, N. L. uklad. (2016). Ukrainska revoliutsiia 1917-1921 pp. na Prydniprov'i: zbirnyk dokumentiv i materialiv [Ukrainian Revolution 1917-1921 pp. on the Dnieper: a collection of documents and materials]. Dnipro: LIRA, 372 s. [in Ukrainian].

Potapov, M. (1957). Chervona hvardiia Katerynoslava [Katerynoslav's Red Guard]. In: Borot'ba za peremohu Radians'koi vlady na Ukraini: zbirnyk spohadiv uchasnykiv Velykoi Zhovtnevoi sotsialistychnoi revoliutsii. Kyiv: Derzhpolitvydav. URSR, s. 253-273. [in Ukrainian].

Rodionov, I. N. glav. red. (1997). Voennaya Entsiklopediya: v 8 t.: t. 1: «A» - Byulov [Military Encyclopedia: in 8 volumes: Vol. 1: «A»—-Byulov]. Moskva: Voenizdat., 639 s. [in Russian].

Slashchev, Ya. (1991). Yekaterinoslavskaya operatsiya [Ekaterinoslav operation]. In: Nestor Ivanovich Makhno: vospominaniya, materialy i dokumenty. Kyiv: Dzvin, s. 84-92. [in Russian].

Stepovyi, Yu. (1947). V Khersonskykh stepakh [In the Kherson steppes]. Miunkhen: Kultura, 127 s. [in Ukrainian].

Sukhanov, A. (1922). Zavoevanie vlasti [Conquest of power]. In: Pyataya godovshchina Oktyabrskoy revolyutsii, 1917-oktyabr-1922. Yekaterinoslav: 1-ya sovetskaya tipografiya, s. 106-113. [in Russian].

Timoshchuk, A. V. (1996). Anarkho-kommunisticheskie formirovaniya N. Makhno (sentyabr 1917 - avgust 1921 g.) [Anarcho-communist formations N. Makhno (September 1917 - August 1921)]. Simferopol: Tavriya, 190 s. [in Russian].

Shved, A. (1927). Pavlogradskaya organizatsiya bolshevikov v 1917 g. [Pavlograd organization of the Bolsheviks in 1917]. In: Borba za Sovety na Yekaterinoslavshchine: sbornik vospominaniy $i$ statey. Dnepropetrovsk: Izdanie Dnepropetrovskogo Istparta i Okruzhnoy komissii po provedeniyu 10-letiya Oktyabrskoy revolyutsii, s. 158-161. [in Russian]. 


\section{Sergiy Zaitsev}

postgraduate student of the Department

of Historical Local Studies

Ivan Franko National University of Lviv

(Lviv, Ukraine)

ORCID: https://orcid.org/0000-0003-2277-9345

\section{COMBAT TRAINING OF FIGHTERS OF THE REBEL-PARTISAN FORMATIONS OF THE KATERYNOSLAV REGION DURING THE PERIOD OF THE UKRAINIAN REVOLUTION (1917-1921)}

The article investigates the peculiarities of combat training, which was a characteristic phenomenon among the fighters of the irregular armed formations that operated in the Katerynoslav region during the Ukrainian Revolution 19171921. It was a purposeful and organized process of military training and education of personnel.

The experience of armed struggle, both in ancient times and today, shows that one of the conditions for the successful combat operations is a properly established process of unit personnel military training. Combat training is an integral part of it. The study of the irregular unit combat training experience is relevant.

On the basis of the archival and published materials, the author distinguished the basic principles of combat training of Bolshevik soldiers, pro-Ukrainian and anarchist irregular rebel-partisan formations that operated in the Katerinoslav region in 1917-1921. In the article the time and reasons for the introduction of combat training in the Bolshevik insurgent and partisan formations are determined; organizations of their training places are revised, skills acquired by militants as a result of training are named. The peculiarities of the combat training of the proUkrainian paramilitary forces and their weaknesses are indicated. The combat training of soldiers and officers of the Revolutionary Insurgent Army of Ukraine (Makhnovists) are evaluated; the main directions of their training are considered.

The methodology of the research is based on the principles of historicism, objectivity and systematization. In the process of research and in solving the problems posed in the work the author relies on the general-historical methods inter alia the historical-comparative, historical-typological and logical.

The study of the problem of irregular combat unit combat training in Katerynoslav region allows to understanding better the principles of the insurgent and partisan forces organization in the region during the Ukrainian Revolution 1917-1921.

Keywords: combat training, Ukrainian Revolution, rebel-partisan movement, Katerynoslav region, Bolshevism, pro-Ukrainian forces, anarchism. 